\title{
PENGARUH SIBLING RELATIONSHIP TERHADAP KESEJAHTERAAN PSIKOLOGIS PESERTA DIDIK SMA NEGERI DI JAKARTA BARAT
}

\author{
Nur Hasanah ${ }^{1}$ \\ Susi Fitri ${ }^{2}$
}

\begin{abstract}
Abstrak
Penelitian ini bertujuan untuk mengetahui perbedaan pengaruh pada dimensi sibling relationship (warmth, relative power, conflict dan rivalry) terhadap kesejahteraan psikologis peserta didik SMA Negeri di Jakarta Barat. Pendekatan yang digunakan dalam penelitian ini ialah pendekatan kuantitatif dengan jenis korelasional. Sampel yaitu 356 peserta didik SMA Negeri di Jakarta Barat (132 laki-laki dan 224 perempuan), usia 15-17 tahun, memiliki saudara kandung. Penentuan sampel menggunakan teknik multistage random sampling. Pengumpulan data menggunakan angket adaptasi, Sibling Relatonship Questionnaire (SRQ) yang disusun oleh Furman dan Buhrmester (1990) sebanyak 48 item dan Scale of Psychological WellBeing (SPWB) milik Ryff (1989) sebanyak 84 item. Uji validitas menggunakan expert judgement dan uji coba instrumen dengan rumus Person's Product Moment. Uji reliabilitas menggunakan rumus Alpha Cronbach dengan SPSS v.25, diperoleh koefisien reliabilitas SRQ sebesar 0,916 dan SPWB sebesar 0,669. Teknik analisis data menggunakan Pearson's Product Moment dan hipotesisnya diuji dengan OneWay ANOVA menggunakan program SPSS v.25. Hasil penelitian menunjukkan bahwa dimensi warmth berpengaruh secara positif terhadap kesejahteraan psikologis peserta didik $(0,178>0,05)$, dimensi relative power berpengaruh secara positif terhadap kesejahteraan psikologis peserta didik $(0,109>0,05)$, dimensi conflict berpengaruh secara negatif terhadap kesejahteraan psikologis peserta didik $(-0,105$ $>0,05)$ dan dimensi rivalry memiliki pengaruh negatif terhadap kesejahteraan psikologis peserta didik $(-0,114>0,05)$. Hasil uji hipotesis ANOVA menunjukkan bahwa $F_{\text {hitung }}>\mathrm{F}_{\text {tabel }}$ atau 4,786 $>2,39$, dengan demikian sibling relationship secara keseluruhan memiliki pengaruh yang berbeda terhadap kesejahteraan psikologis peserta didik SMA Negeri di Jakarta Barat. Namun, berdasarkan hasil Pearson Correlation dibandingkan dengan tabel koefisien korelasi, didapati bahwa pengaruh yang terjadi dari masing-masing dimensi pada sibling relationship terhadap kesejahteraan psikologis peserta didik sangat rendah. Uji Tukey HSD juga menunjukkan bahwa hanya dimensi rivalry yang memiliki pengaruh berbeda dengan ketiga dimensi lainnya (warmth, relative power, conflict) terhadap kesejahteraan psikologis peserta didik SMA Negeri di Jakarta Barat.
\end{abstract}

Kata Kunci: hubungan persaudaraan, kesejahteraan psikologis

\footnotetext{
${ }^{1}$ Universitas Negeri Jakarta, nur.hasanah169@gmail.com

${ }^{2}$ Universitas Negeri Jakarta, susi.fitri@unj.ac.id
} 


\begin{abstract}
This study aims to determine the difference in affect of dimensions of sibling relationship (warmth, relative power, conflict and rivalry) on psychological wellbeing in senior high school students at West Jakarta. Suggestions used in this research are quantitative with correlational type. The samples were 356 high school students at West Jakarta (132 males and 224 females), age 15-17, has sibling. Determination of the sample multistage random sampling technique. Data collected by forms of an questionnaire which adapted, that is Sibling Relationship Questionnaire (SRQ) organized by Furman and Buhrmester (1990) amount 48 items, and Scale of Psychological Well-Being (SPWB) by Ryff (1989) amount 84 items. Validity test uses expert judgement and instrument testing with the Pearson's Product Moment. Realibility test using the Cronbach Alpha with SPSS v.25 obtained the reliability coefficient $S R Q$ is 0,916 and SPWB is 0.669. Data analyzed using Pearson's Product Moment and the hypothesis was tested by One-Way ANOVA with SPSS v.25. The results showed that warmth dimension had a positive effect on psychological well-being of students $(0,178>0,05)$, relative power dimension had a positive effect on psychological well-being of students $(0,109>0,05)$, conflict dimension had a negative effect on psychological well-being of students (- 0,105 > $0,05)$, and rivalry dimension had a negative effect on psychological well-being of students $(-0,114>0,05)$. Hypothesis test by ANOVA results that $F_{\text {count }}>F_{\text {table }}$ or $4,786>2,39$, means sibling relationship has a different effect on psychological wellbeing in senior high school students at West Jakarta. However, based on the results of Pearson Correlation compared to the correlational coefficient table, was found that the effect of each diomension of sibling relationship on psychological well-being of students was very low. Tukey HSD test also shows that only rivalry dimension has a different effect from the other three dimensions (warmth, relative power, conflict) on psychlogicall well-being in senior high school students at West Jakarta.
\end{abstract}

Keywords: Sibling relationship, psychological well-being

\section{PENDAHULUAN}

Sibling relationship memiliki andil dalam pembentukan kepribadian dalam diri. Sibling relationship adalah hubungan keseharian yang memiliki kontak paling intim yang dialami oleh seorang anak terhadap anak lain karena berada dalam satu rumah (Cicirelli, 1995). Hubungan saudara adalah aspek penting dari perkembangan anak karena mempengaruhi anak-anak berkembang (Sanders, 2004). Hal ini karena saudara kandung menghabiskan lebih banyak waktu dengan satu sama lain daripada dengan orang lain serta merupakan posisi terlama yang dimiliki seseorang.
Keintiman hubungan yang berdasarkan intensitas dan kedekatan tersebut memiliki dampak resiprokal pada individu.

Hubungan saudara kandung dapat berdampak pada keterampilan sosial dan kognitif yang penting bagi perkembangan sosial yang sehat. Sebaliknya, hubungan yang buruk dengan saudara kandung dapat memberikan kesempatan pada individu untuk melakukan perilaku delikuensi, sebagai hasil dari interaksi negatifnya dengan saudara kandung di rumah (Roja, 2013). Salah satunya, sibling relationship memiliki peran sebagai salah satu faktor penting dalam kesejahteraan psikologis seseorang (Thomas dkk., 2017). Hal ini 
karena kedekatan interaksi dengan saudara kandung pada remaja yang memiliki selfesteem tinggi dapat meningkatkan perilaku prososialnya (Riska dkk., 2018). Sedangkan individu yang memiliki kesejahteraan psikologis rendah cenderung jarang merasakan kebahagiaan, self-efficacy rendah dan memiliki tingkat depresi tinggi yang merupakan bagian dari salah satu dimensi kesejahteraan psikologis, yaitu penerimaan diri, otonomi dan pengembangan diri.

Salah satu periode dalam rentang kehidupan seseorang ialah (fase) remaja. Masa ini merupakan fase kehidupan yang penting dalam siklus perkembangan individu, dan merupakan masa transisi untuk mencapai perkembangan masa dewasa yang sehat. Untuk dapat melakukan sosialisasi dengan baik, remaja harus menjalankan tugas-tugas perkembangannya dengan baik. Apabila tugas perkembangan ini dapat dilakukan dengan baik, maka remaja tidak akan mengalami kesulitan dalam kehidupan sosialnya serta akan mencapai kesuksesan dalam menuntaskan tugas perkembangan untuk fase-fase berikutnya (Saputro, 2018). Namun jika remaja tidak dapat melaksanakan perannya dengan baik maka akan timbul permasalahan berupa kenakalan remaja seperti narkoba, merokok, free sex, tawuran, pencurian dan berbagai tindak kriminal yang menyimpang dari norma masyarakat .

Pada masa ini kesejahteraan psikologis mulai berkembang, ditandai dengan mulai terlibat dalam kegiatan sosial, berempati, dapat mengelola emosi dengan baik serta memiliki tanggung jawab yang tinggi. Ramadhani, Djunaedi dan Sismiati (2016) menyatakan bahwa peserta didik yang memiliki kesejahteraan psikologis tinggi dapat melewati tugas-tugas perkembangan, menghadapi tantangan, menjalankan hidupnya dengan bahagia, tenang dan mampu mengatasi segala masalah yang dihadapi. Hal ini berkaitan dengan pentingnya relasi persaudaraan pada masa remaja. Seperti yang diungkapkan McCoy, Brody, dan Stoneman (2002) bahwa hubungan antar saudara yang dipenuhi oleh perilaku positif akan membuat hubungan individu dengan lingkungan seperti teman sebaya lebih positif. Sebaliknya hubungan antar saudara yang dipenuhi oleh perilaku negatif dapat melemahkan motivasi individu untuk menjalin hubungan dan mengadakan kontak sosial yang lebih luas dengan orang di luar lingkungan keluarga. Fardiayanti (2017) menyatakan bahwa remaja yang memiliki hubungan saudara yang buruk akan cenderung memiliki hubungan yang kurang baik dengan teman sebayanya.

Suherman dalam (Kamaluddin, 2011) mengungkapkan bahwa terdapat sepuluh fungsi bimbingan dan konseling. Diantara fungsi-fungsi tersebut beberapa saling berkait antara fungsi layanan BK dengan kesejahteraan psikologis pada hubungan saudara yang menjadi penting bagi guru BK dalam melakukan layanan bimbingan. Salah satunya yaitu fungsi preventif, kuratif dan pemeliharaan.

Fungsi preventif merupakan upaya guru BK untuk mengantisipasi dan mencegah kemungkinan masalah yang dapat terjadi dengan memberikan bimbingan, baik secara klasikal maupun kelompok. Seperti cara menerima diri, mengoptimalkan kemampuan, dan menjalin hubungan interpersonal yang hangat, baik dengan teman di sekolah maupun saudara kandung di rumah. Hal ini sesuai dengan Standar Kompetensi Kemandirian Peserta Didik SMA pada aspek pengembangan diri; guru BK membantu peserta didik untuk dapat menerima keunikan diri dengan kelebihan dan kekurangannya. Lalu aspek kesadaran tanggung jawab sosial, yaitu menyadari nilai persahabatan dan keharmonisan dalam konteks interaksi sosial (Sugiyatno, 2014).

Fungsi kuratif ialah fungsi bimbingan dan konseling yang tujuannya untuk memberikan bantuan kepada peserta didik yang memiliki masalah melalui layanan konseling individu maupun kelompok. Pada layanan konseling, penelitian ini penting dalam fungsi kuratif sebagai referensi untuk mengidentifikasi sebab, akibat dan dampak yang ditimbulkan dari hubungan persaudaraan seseorang dan pengaruhnya 
terhadap kesejahteraan psikologisnya serta membantu menentukan teknik yang tepat dalam konseling, mengoptimalkan pemberian layanan informasi di sekolah.

Fungsi pemeliharaan, yaitu fungsi bimbingan dan konseling untuk membantu individu supaya dapat menjaga diri dan mempertahankan situasi kondusif yang telah tercipta dalam dirinya agar terhindar dari kondisi-kondisi yang akan menyebabkan penurunan produktivitas diri, termasuk salah satunya jika individu memiliki masalah dengan saudara kandungnya. Hal ini berkaitan dengan perkembangan psikologis individu yang meliputi perasaan dan emosi positif mengenai diri mereka (Kamaluddin, 2011).

Oleh karena itu, penelitian ini penting dilakukan untuk mengetahui gambaran pengaruh sibling relationship peserta didik terhadap kesejahteraan psikologisnya agar dapat mengoptimalkan pemberian layanan bimbingan dan konseling pada peserta didik.

Berdasarkan studi pendahuluan yang dilakukan oleh peneliti, dari hasil wawancara dengan guru BK SMAN 95 Jakarta, dikatakan bahwa pelaksanaan layanan bimbingan dan konseling di sekolah kurang terlaksana. Hasil wawancara dengan Guru BK SMAN 95 Jakarta menunjukkan bahwa guru BK tidak pernah menangani dan memberi layanan mengenai Sibling relationship dan kesejahteraan psikologis remaja di SMA tersebut. Guru BK juga tidak pernah menangani konseling terkait kedua masalah tersebut. Pemberian layanan bimbingan dan konseling, khususnya layanan responsif masih kurang maksimal dikarenakan kurangnya pengetahuan guru BK dan latar belakang pendidikan yang bukan dari Bimbingan dan Konseling.

Kemudian berdasarkan hasil angket studi pendahuluan kepada 30 Peserta Didik di SMAN 95 Jakarta, dapat disimpulkan bahwa terdapat permasalahan terkait sibling relationship dan kesejahteraan psikologis pada peserta didik di SMAN 95 Jakarta. Berdasarkan hasil studi pendahuluan menggunakan angket didapati bahwa $45 \%$ peserta didik di SMAN 95 Jakarta memiliki warmth relationship. Peserta didik tersebut cenderung dapat menerima kekurangan dan kelebihannya, namun belum merasa puas akan dirinya, dan secara otonomi masih membutuhkan orang lain untuk membantunya mengambil keputusan akan tetapi telah memiliki rencana hidup dalam 10 tahun kedepan. Kemudian $33.3 \%$ peserta didik memiliki relative power relationship. Peserta didik dengan sibling relationship dimensi ini jarang berdiskusi atau menceritakan masalahnya dengan saudara kandungnya, juga belum dapat menerima kekurangan dan kelebihannya, belum merasa puas akan prestasi yang di dapatkan serta merasa kesulitan dalam mengatur kehidupannya saat ini. Sebesar 16.6\% peserta didik memiliki conflict relationship dengan saudara kandungnya. Peserta didik dengan dimensi ini memiliki tempramen yang sama dengan saudara kandungnya dan orangtua selalu membandingkan keduanya. Selain itu peserta didik yang memiliki dimensi ini juga cenderung belum dapat menerima kekurangan diri dan merasa kesulitan menyampaikan pendapat kepada orang lain. Dan sebanyak 5\% peserta didik memiliki rivalry relationship. Kesejahteraan psikologis pada peserta didik yang memiliki hubungan dengan saudara kandung pada dimensi ini didapati tidak terlalu mempengaruhi dirinya.

Fahmi dan Handayani (2018) dalam penelitiannya mengenai hubungan antara dimensi sibling relationship (warmth, relative status/power, conflict dan rivalry) dengan psychological well-being pada remaja yang mempunyai saudara kandung down syndrome, menyatakan adanya hubungan pada dimensi warmth/ closenes, conflict, dan rivalry dengan psychological well-being namun tidak pada dimensi power.

Oleh karena itu penelitian ini dilakukan untuk mengetahui apakah terdapat perbedaan pengaruh sibling relationship terhadap kesejahteraan psikologis peserta didik SMA Negeri di Jakarta Barat. Peserta didik dengan dimensi sibling relationship (warmth, relative status/power, conflict dan 
rivalry) memiliki tingkat kesejahteraan psikologis yang berbeda.

\section{Kesejahteraan Psikologis}

Menurut Ryff (1995) kesejahteraan psikologis merupakan usaha untuk merealisasikan potensi sesungguhnya dalam diri seseorang. Prabowo (2016) mengemukakan bahwa kesejahteraan psikologis adalah keadaan individu yang mampu menerima dirinya apa adanya, dapat membentuk hubungan hangat dengan orang lain, memiliki kemandirian terhadap tekanan sosial, mampu mengontrol kondisi lingkungan eksternal, memiliki tujuan hidup serta mampu merealisasikan kemampuan dirinya. Selanjutnya Savitri dan Listiyandini (2017) menyatakan bahwa kondisi kesejahteraan psikologis yang baik diikuti dengan tingginya perilaku prososial dan tampak dari keberfungsian yang optimal pada seluruh aspek perkembangan psikologis yang meliputi perasaan dan emosi positif mengenai diri, mampu menyelesaikan masalahnya serta memiliki hubungan sosial yang baik.

Oleh karena itu, dapat disimpulkan bahwa kesejahteraan psikologis ialah keadaan individu yang mampu menerima dirinya dan dapat merealisasikan potensi diri yang sesungguhnya sehingga dapat mengoptimalkan perilaku prososial serta memiliki perasaan dan emosi positif mengenai diri pada seluruh aspeknya.

Kesejahteraan psikologis terdiri dari enam dimensi yaitu penerimaan diri, tujuan hidup, pengembangan diri, hubungan yang positif dengan orang lain, penguasaan terhadap lingkungan, dan otonomi (Ryff, 1995). 1) Penerimaan diri, merupakan aspek yang menggambarkan sikap positif individu terhadap diri sendiri dan menggambarkan evaluasi diri yang positif, kemampuan mengakui aspek diri sendiri, dan menerima positif dan negatif kemampuan seseorang; 2) hubungan yang positif dengan orang lain, berkaitan dengan kemampuan menjalin hubungan antar pribadi yang hangat dan saling mempercayai; 3 ) otonomi merupakan kemampuan untuk menentukan pilihan hidup, mandiri dan mengatur perilakunya sendiri. Kemudian, 4) penguasaan lingkungan yang meliputi rasa penguasaan dan kompetensi serta kemampuan memilih situasi dan lingkungan yang kondusif; 5) tujuan hidup meliputi kesadaran akan tujuan dan makna hidup, serta arah dan keyakinankeyakinan yang memberikan perasaan pada individu bahwa ada tujuan dan makna dalam hidupnya. Serta, 6) pengembangan diri, yaitu merupakan kemampuan diri mengembangkan potensi dirinya untuk tumbuh dan berkembang sebagai individu secara efektif pribadi meliputi kapasitas tumbuh untuk mengembangkan potensi, pribadi dari waktu ke waktu, pengetahuan diri dan efektivitas.

Nastasi dan Borja

mengemukakan bahwa kesejahteraan psikologis dipengaruhi oleh faktor individu dan kultural. Faktor individu terdiri dari (a) penilaian kompetensi seperti akademik, tingkah laku, dan fisik; (b) kerentanan pribadi seperti latar belakang keluarga, memiliki cacat; (c) keterampilan pribadi seperti keterampilan dalam berhubungan, memecahkan masalah dan mekanisme pertahanan diri. Sedangkan faktor budaya meliputi (a) sumber daya sosial seperti teman sebaya, komunitas, saudara dan sekolah; (b) norma budaya, misalnya peran gender dan hubungan dengan orang dewasa; (c) agen sosialisasi seperti guru, teman dan orangtua; (d) praktek sosialisasi seperti pendidikan dan disiplin; dan (e) sosial budaya misalnya konflik dengan keluarga, kemiskinan dan kekerasan di lingkungan.

\section{Sibling Relationship}

Buhrmester dan Furman (1990) menyatakan bahwa relasi antar saudara (sibling relationship) sangat mempengaruhi pemahaman individu terhadap hubungan interpersonal. Relasi antar saudara dapat membentuk rasa pertemanan, dukungan, dan memunculkan kualitas positif yang mendorong sikap prososial seperti tolongmenolong, berbagi dan empati. Menurut Sanders (2004) sibling relationship adalah aspek penting dari perkembangan individu karena mempengaruhi individu berkembang 
terutama secara sosial dan bermotif. Saudara dapat menumbuhkan sikap mencintai dan membenci yang menimbulkan keinginan untuk eksis serta memungkinkan berkembangnya ego individu secara signifikan. Hal ini karena saudara kandung menghabiskan lebih banyak waktu dengan satu sama lain daripada dengan orang lain, serta hubungan saudara kandung mungkin merupakan posisi terlama yang dimiliki seseorang (Cicirelli, 1995).

Maka dapat disimpulkan bahwa sibling relationship adalah hubungan antar dua individu atau lebih yang memiliki orangtua biologis yang sama dan saling mempengaruhi perkembangan satu sama lain. Hubungan antar saudara kandung tersebut dapat mempengaruhi sikap individu dalam berhubungan secara intrapersonal maupun interpersonal. Hubungan ini memunculkan kesadaran diri, subjektivitas, yang kontradiktif, terpecah, tidak rasional, dan sampai pada taraf tertentu tidak teridentifikasi.

Furman dan Buhrmester (1985) dalam penelitiannya mengemukakan bahwa sibling relationship terdiri dari empat dimensi. Dimensi-dimensi tersebut adalah rangkuman dari beberapa pola hubungan saudara kandung yang dimiliki seseorang dengan kriteria tertentu. 1) Dimensi warmth menunjukkan hubungan kedekatan dan kehangatan antar saudara; 2) dimensi relative power, menunjukkan pengaruh dan kekuasaan antar saudara yang dipengaruhi oleh mendominasi atau didominasi oleh saudara kandung. Selanjutnya, 3) dimensi conflict, menunjukkan adanya pertentangan antar saudara yang terdiri dari sifat antargonis, kompetisi dan yang difavoritkan orangtua. Selain itu juga terdiri dari aspekaspek negatif seperti perdebatan, agresi, permusuhan, negativitas dan paksaan (Sanders, 2004); 4) Dimensi rivalry adalah hubungan persaudaraan yang menunjukkan adanya rasa cemburu atau persaingan antar saudara untuk mendapatkan perhatian orangtua. Dimensi rivalry terjadi karena faktor frekuensi pertengkaran, favoritisme orangtua, perbedaan usia, jumlah keluarga inti, dan keterlibatan orangtua dalam pengasuhan.

Furman \& Buhrmester (1985) menjelaskan faktor-faktor dalam sibling relationship sebagai berikut: 1) Dimensi warmth dipengaruhi oleh intimasi, afeksi, perilaku prososial, persahabatan, dan kedekatan antar saudara kandung. Biasanya terjadi pada saudara dengan jenis kelamin sama dan jarak usia > 4 tahun. 2) Dimensi relative power dipengaruhi oleh usia relatif. (Cicirelli, 1973) mendapati bahwa pengasuhan dan dominasi yang lebih besar dirasakan oleh saudara kandung yang lebih muda terhadap saudara kandung yang lebih tua. Ketika individu berusia 4 tahun atau lebih, saudara yang lebih tua cenderung terlibat dalam kegiatan mengasuh dan merawat adik-adiknya sehingga saudara kandung yang lebih muda menjadikan kakaknya sebagai figur model. Kekaguman terhadap saudara kandung kurang didapati ketika jarak usia keduanya sempit. 3) Dimensi conflict disebabkan oleh faktorfaktor seperti pertengkaran, kepribadian anak, pertentangan, dan favoritisme orangtua. Stocker dkk (Stoneman \& Brody, 1993) menjelaskan bahwa temperamen saudara kandung menyebabkan perbedaan dalam menjelaskan aspek kualitatif dari hubungan saudara. Temperamen yang tinggi pada anak-anak berkaitan dengan peningkatan empat kali lipat konflik dalam hubungan persaudaraan. 4) Dimensi rivalry terjadi karena faktor frekuensi pertengkaran, perilaku orangtua terhadap saudara yang lain, perbedaan usia antar saudara, jumlah keluarga inti dan anak yang difavoritkan orangtua. Dimensi ini muncul karena jarak usia yang dekat. Leung \& Robson (1991) menyatakan bahwa anak dengan perbedaan usia 2-4 tahun menampilkan perilaku yang lebih parah.

\section{METODE PENELITIAN}

Penelitian ini bertujuan untuk melihat perbedaan pengaruh sibling relationship terhadap kesejahteraan psikologis peserta didik SMA Negeri di Jakarta Barat. Metode penelitian ini adalah penelitian korelasi yang 
bersifat asosiatif dengan pendekatan kuantitatif. Penelitian kuantitatif adalah suatu proses menemukan pengetahuan yang menggunakan data berupa angka sebagai alat menemukan keterangan mengenai apa yang ingin diketahui. Penelitian ini diuji dengan hipotesis statistik, yaitu prosedur yang memungkinkan keputusan dapat dibuat baik untuk menolak atau tidak menolak hipotesis yang sedang dipersoalkan/diuji. Pengujian hipotesis dalam penelitian ini menggunakan ANOVA dengan bantuan aplikasi Statistical Package for the Social Sciences (SPSS) version 25.0.

Populasi penelitian ini ialah peserta didik SMA Negeri di Jakarta Barat. Penelitian ini menggunakan teknik pengambilan sampel Multistage Random Sampling. Hasilnya diperoleh sampel sebanyak 356 peserta didik sebagai responden. Instrumen yang digunakan adalah Sibling Relationship Questionnaire (SRQ) oleh Furman dan Buhrmester berjumlah 42 butir. Scale of Psychological Well-Being (SPWB) oleh Ryff yang memiliki 84 butir item.

\section{HASIL PENELITIAN}

Penelitian ini dilakukan di SMA Negeri di wilayah Jakarta Barat dengan menyebarkan instrumen kepada 356 peserta didik dari delapan sekolah. Hasil peneitian ini dihitung menggunakan presentase dan hipotesisnya menggunakan uji ANOVA.

\section{Pengaruh Dimensi Sibling Relationship terhadap Kesejahteraan Psikologis}

Hasil uji analisis korelasi Pearson's Product Moment variabel sibling relationship (X); dimensi warmth $\left(\mathrm{X}_{1}\right)$, dimensi relative power $\left(\mathrm{X}_{2}\right)$, dimensi conflict $\left(\mathrm{X}_{3}\right)$, dan dimensi rivalry $\left(\mathrm{X}_{4}\right)$ terhadap variabel kesejahteraan psikologis adalah sebagai berikut.

\begin{tabular}{|c|c|c|}
\hline \multicolumn{2}{|c|}{ Sibling Relationship } & Kesejahteraan \\
\hline Warmth & Pearson & 0.178 \\
\hline & $\begin{array}{l}\text { Correlation } \\
\text { Sig. (2-tailed) }\end{array}$ & 0.001 \\
\hline Relative & Pearson & 0.109 \\
\hline Power & Correlation & 0040 \\
\hline Conflict & $\begin{array}{l}\text { Pearson } \\
\text { Peall }\end{array}$ & $\begin{array}{r}-0.105 \\
-0.05\end{array}$ \\
\hline & $\begin{array}{l}\text { Correlation } \\
\text { Sig. (2-tailed) }\end{array}$ & 0.047 \\
\hline Rivalry & $\begin{array}{l}\text { Pearson } \\
\text { Correlation }\end{array}$ & -0.114 \\
\hline & Sig. (2-tailed) & 0.032 \\
\hline
\end{tabular}

Tabel 1.1 Uji Korelasi Pearson's Product Moment

Berdasarkan hasil analisis data pada tabel 1.1 dapat diketahui bahwa dimensi warmth memiliki pengaruh positif terhadap kesejahteraan psikologis dengan korelasi sebesar 0,178 >0,05. Nilai signifikansinya menunjukkan angka $0,001<0,05$. Oleh karena itu dapat disimpulkan bahwa terdapat hubungan positif yang signifikan antara dimensi warmth dengan kesejahteraan psikologis signifikan. Artinya, semakin tinggi dimensi warmth maka semakin tinggi pula kesejahteraan psikologisnya. Sebaliknya, semakin rendah dimensi warmth maka semakin rendah pula kesejahteraan psikologis peserta didik.

Hasil penelitian ini didukung oleh penelitian yang dilakukan Fahmi dan Handayani (2018) mengenai hubungan antara dimensi sibling relationship dengan kesejahteraan psikologis pada remaja yang memiliki saudara down syndrome. Penelitian tersebut menyatakan bahwa terdapat hubungan yang positif antara dimensi warmth dengan kesejahteraan psikologis. Marotta (2015) dalam penelitiannya tentang hubungan antara kualitas sibling relationship dan psychological outcome pada masa emerging adulthood, menyatakan bahwa kehangatan dalam hubungan persaudaraan dapat mengarahkan individu pada penurunan distress, depresi dan kecemasan. Individu yang memiliki hubungan yang hangat (warmth) dengan saudara kandungnya akan meningkatkan self-esteem dan 
meningkatkan hubungan dengan teman sebayanya (Sherman dkk., 2006) serta menurunkan gejala depresi (Kim dkk., 2007).

Berdasarkan hasil analisis data pada tabel 1.1 dapat diketahui bahwa dimensi relative power memiliki pengaruh positif terhadap kesejahteraan psikologis dengan korelasi sebesar $0,109>0,05$. Nilai signifikansinya menunjukkan angka $0,040<$ 0,05 . Oleh karena itu dapat disimpulkan bahwa hubungan yang terjadi antara dimensi relative power dengan kesejahteraan psikologis bernilai positif dan signifikan. Azmitia dan Hesser (1993) mengemukakan bahwa hubungan saudara kandung yang dimiliki kakak-beradik memiliki fungsi unik yang dapat membantu perkembangan kognitif individu dalam belajar ketika hasilnya dibandingkan dengan hubungan pertemanan individu tersebut. Bagi saudara kandung yang lebih tua, mengasuh saudara kandung dengan meluangkan waktu untuk mengajarkan adiknya belajar diketahui berdampak pada tingginya skor membaca dan kemampuan bahasa pada dirinya jika dibandingkan dengan teman sekelasnya yang juga memiliki saudara kandung namun tidak mengajarkannya belajar (Brody, 1998).

Kemudian, berdasarkan hasil analisis korelasi pada tabel 1.1 diketahui bahwa dimensi conflict memiliki pengaruh negatif terhadap kesejahteraan psikologis dengan korelasi sebesar $0,105>0,05$. Nilai signifikansinya menunjukkan angka $0,047<$ 0,05 . Maka dapat disimpulkan bahwa hubungan yang terjadi antara dimensi conflict dengan kesejahteraan psikologis bernilai negatif dan signifikan.

Dimensi conflict pada hubungan antar saudara kandung dapat memberikan dampak penurunan kesejahteraan psikologis pada individu karena banyaknya emosi negatif yang ada dapat menurunkan self-worth (Azmitia \& Hesser, 1993). Tingginya conflict dalam hubungan persaudaraan juga dinilai menjadi faktor tidak langsung yang memperburuk dampak negatif stres (Van Langeveld, 2010) serta dapat meningkatkan gejala depresi (Kim dkk., 2007). Conflict pada hubungan persaudaraan berkontribusi meningkatkan sibling bullying (Menesini dkk., 2010).

Selanjutnya, hasil penelitian ini juga menunjukkan bahwa dimensi rivalry memiliki pengaruh negatif terhadap kesejahteraan psikologis dengan korelasi sebesar 0,114 >0,05. Nilai signifikansinya menunjukkan angka $0,032<0,05$. Oleh karena itu dapat disimpulkan bahwa hubungan yang terjadi antara dimensi rivalry dengan kesejahteraan psikologis bernilai negatif dan signifikan.

Hasil penelitian ini didukung oleh penelitian Fahmi dan Handayani (2018) tentang hubungan antara dimensi sibling relationship dengan kesejahteraan psikologis pada remaja yang memiliki saudara down syndrome dan penelitian Pertiwi (2019) tentang hubungan antara sibling rivalry dengan kesejahteraan psikologis pada siswa kelas kelas VII SMP Negeri 12 semarang. Hasil kedua penelitian tersebut menyatakan bahwa terdapat hubungan antara dimensi rivalry dengan kesejahteraan psikologis pada remaja yang memiliki arah hubungan negatif. Individu dengan sibling rivalry dapat menurunkan kondisi kesejahteraan psikologis karena dapat meningkatkan stres (Yanuari \& Rahmasari, 2011) dan menurunkan selfesteem (Marotta, 2015). Seperti yang dijelaskan Maiorano (Pertiwi \& NRH, 2019) bahwa individu dengan sibling rivalry memiliki tingkat kecemasan yang tinggi, rentan terhadap depresi, harga diri yang rendah, dan penyesuaian yang buruk di sekolah.

Dalam penelitian ini juga ditemukan bahwa perbedaan pengaruh yang terjadi antara dimensi warmth dan dimensi relative power terhadap kesejahteraan psikologis tidaklah signifikan. Hal ini diasumsikan terjadi karena pengasuhan oleh saudara kandung memunculkan kehangatan dan hubungan yang harmonis antar saudara kandung pada dimensi relative power, yang berdampak positif pada kognitif individu (Azmitia \& Hesser, 1993) dan hubungan 
interpersonal (Van Langeveld, 2010). Kemudian hubungan relative power yang dimiliki individu dengan saudara kandungnya juga dapat berubah menjadi warmth seiring perkembangan individu dari remaja menuju dewasa karena hubungan yang terjadi antar saudara kandung menjadi egaliter (Lindell \& Campione-Barr, 2017). Penelitian lebih lanjut diperlukan.

Selain itu, temuan dalam penelitian ini juga menyatakan bahwa perbedaan pengaruh antara dimensi warmth dan dimensi conflict terhadap kesejahteraan psikologis tidak signifikan. Hal ini diasumsikan karena konflik pada tingkat tertentu, jika tidak berlebihan atau diikuti dengan kekerasan, dianggap normatif dalam hubungan persaudaraan (Alkema, 2013). Furman dan Buhrmester (1990) menyatakan bahwa kedua dimensi tersebut tidak berkorelasi karena kualitas negatif dan positifnya tidaklah benar-benar berlawanan. Beberapa interaksi negatif pada hubungan sauadara dapat berpengaruh positif pada perkembangan individu karena hal tersebut berkontribusi meningkatkan keterampilan sosial, negosiasi konflik (Stormshak dkk., 2009) dapat memicu responsivitas emosional dan kemampuan penalaran yang dipelajari dari interaksi antar saudara kandung. Brody (1998) mengemukakan bahwa konflik dan dukungan dari saudara yang seimbang berpengaruh positif terhadap hubungan individu dengan teman sebaya dan penyesuaian diri di sekolah.

\section{Pengaruh Sibling Relationship terhadap Kesejahteraan Psikologis}

Berikut adalah hasil pengujian hipotesis ANOVA antara variabel sibling relationship terhadap kesejahteraan psikologis.

\begin{tabular}{|c|c|c|}
\hline & $\begin{array}{c}\text { Between } \\
\text { Groups }\end{array}$ & $\begin{array}{l}\text { Within } \\
\text { Groups }\end{array}$ \\
\hline $\begin{array}{l}\text { Sum of } \\
\text { Squares }\end{array}$ & 1611.578 & 39505.936 \\
\hline$d f$ & 3 & 352 \\
\hline Mean Square & 537.193 & 112.233 \\
\hline$F$ & 4.786 & \\
\hline Sig. & 0.003 & \\
\hline
\end{tabular}

Berdasarkan hasil uji ANOVA didapati bahwa nilai $\mathrm{F}_{\text {hitung }}=4,786$. Hal ini berarti $F_{\text {hitung }}>F_{\text {tabel }}$ atau 4,786 lebih besar dari 2.39, maka $\mathrm{H}_{0}$ ditolak. Artinya terdapat pengaruh antara variabel sibling relationship; warmth $\left(\mathrm{X}_{1}\right)$, relative power $\left(\mathrm{X}_{2}\right)$, conflict $\left(\mathrm{X}_{3}\right)$, dan rivalry $\left(\mathrm{X}_{4}\right)$ secara simultan terhadap variabel kesejahteraan psikologis (Y). Uji ANOVA juga menunjukkan nilai signifikansi sebesar 0,003 yang artinya lebih kecil dari taraf signifikansi 0,05. Maka dapat disimpulkan bahwa terdapat pengaruh yang signifikan antara sibling relationship terhadap kesejahteraan psikologis.

Hubungan persaudaraan yang positif diketahui dapat mempengaruhi kesejahteraan psikologis individu (Naretey, 2013). Afeksi yang tinggi (warmth) pada saudara kandung dapat memberikan efek langsung pada kesejahteraan psikologis anak (Van Langeveld, 2010). Hal ini (Van Langeveld, 2010) sesuai dengan Milevsky (2019) yang menyatakan bahwa individu dengan dimensi warmth dan relative power berkorelasi dengan tercapainya penerimaan dan pengembangan diri yang mengarah pada kepuasan hidup terutama jika hal ini dikaitkan dengan dinamika saudara kandung di masa dewasa. Individu yang memiliki skor tinggi pada dimensi warmth dan relative power menunjukkan tekanan psikologis rendah (Paula, 2012) karena individu memiliki penerimaan diri yang baik. Fahmi dan Handayani (2018) dalam penelitiannya tentang hubungan antara dimensi pada sibling relationship dengan kesejahteraan psikologis pada remaja yang memiliki saudara down syndrome, menyatakan bahwa terdapat hubungan antara dimensi sibling relationship pada dimensi warmth, conflict, dan rivalry dengan kesejahteraan psikologis.

Hasil penelitian ini juga mendapati bahwa pengaruh yang terjadi antara keempat dimensi pada sibling relationship terhadap kesejahteraan psikologis peserta didik sangat rendah. Peneliti berasumsi hal ini terjadi karena terdapat faktor lain seperti kepribadian dan hubungan dengan orangtua yang memiliki pengaruh lebih terhadap 
kondisi kesejahteraan psikologis seseorang. Kavčič dan Zupančič (2011) dalam penelitiannya tentang hubungan sibling relationship dan kepribadian anak di awal/pertengahan masa kecil dari persepsi orangtua mengemukakan bahwa kepribadian saudara kandung yang lebih tua berkontribusi dalam mengembangkan cara saudara kandungnya yang lebih muda menjalin hubungan dengan orang lain. Kemudian, Azmitia dan Hesser (1993) dalam penelitiannya untuk mengetahui pentingnya peran saudara kandung dalam perkembangan kognitif saudara kandungnya jika dibandingkan dengan teman sebaya menyatakan bahwa kemampuan kognitif individu memang lebih meningkat jika diajarkan oleh saudara kandungnya dibandingkan teman sebaya, namun ibu berperan lebih pending dalam meningkatkan kemampuan kognitif individu ika dibandingkan dengan saudara kandung dan teman sebaya. Hal tersebut karena ibu dinilai lebih mahir daripada saudara kandung dalam menyampaikan informasi konseptual kepada anaknya karena rasa kepedulian ibu lebih besar terhadap proses belajar dibandingkan saudara kandung. Hubungan dengan orangtua berkorelasi positif dengan sibling relationship dan kesejahteraan psikologis (Naretey, 2013).

\section{KESIMPULAN}

\footnotetext{
Terdapat pengaruh antara sibling relationship terhadap kesejahteraan psikologis peserta didik SMA Negeri di Jakarta Barat. Dimensi warmth pada sibling relationship berpengaruh positif terhadap kesejahteraan psikologis peserta didik SMA Negeri di Jakarta Barat. Dimensi relative power pada sibling relationship memiliki pengaruh positif terhadap kesejahteraan psikologis peserta didik SMA Negeri di Jakarta Barat. Semakin tinggi dimensi warmth atau relative power, maka semakin tinggi pula kesejahteraan psikologisnya. Selanjutnya, dimensi conflict pada sibling relationship memiliki pengaruh negatif terhadap kesejahteraan psikologis peserta didik SMA Negeri di Jakarta Barat. Dan
}

dimensi rivalry pada sibling relationship memiliki pengaruh negatif terhadap kesejahteraan psikologis peserta didik SMA Negeri di Jakarta Barat. Semakin tinggi dimensi conflict atau rivalry; maka semakin rendah kesejahteraan psikologisnya. Sebaliknya, semakin rendah dimensi conflict atau rivalry maka semakin tinggi kesejahteraan psikologis peserta didik.

Berdasarkan hasil penelitian yang telah diuraikan di atas, maka beberapa saran yang dapat menjadi pertimbangan kepada berbagai pihak yang terkait, antara lain:

1. Guru Bimbingan dan Konseling

Guru BK dapat menggunakan hasil penelitian ini sebagai salah satu acuan dalam melakukan layanan preventif maupun kuratif. Dukungan tersebut dapat diaplikasikan dalam bentuk psikoedukasi tentang pentingnya komunikasi yang baik dengan saudara kandung maupun program bimbingan dan konseling untuk meningkatkan kesejahteraan psikologis peserta didik agar dapat mengoptimalkan potensi yang dimiliki. Jika terjadi konseling terkait kondisi kesejahteraan psikologis peserta didik, guru BK dapat menjadikan hal ini sebagai salah satu pertimbangan penyebab.

2. Peneliti Selanjutnya

Jika peneliti ingin melakukan penelitian lebih lanjut, maka sebaiknya peneliti menggunakan/menambahkan variabel independen lain yang tidak digunakan dalam penelitian ini untuk mengetahui pengaruh kesejahteraan psikologis peserta didik. Peneliti juga dapat meneliti lebih lanjut tentang pengaruh yang terjadi antara dimensi relative power dan keterkaitannya dengan kedua dimensi lainnya yaitu warmth dan conflict terhadap kesejahteraan psikologis. Atau mengubah subyek penelitian dari remaja menjadi dewasa untuk mengetahui apakah pengaruh pada dimensi sibling relationship pada 
peserta didik tehadap kesejahteraan psikologis memiliki perbedaan.

\section{DAFTAR PUSTAKA}

Alkema, N. L. (2013). Associations between sibling relationship quality and emotional competence in middle childhood. California State University.

Azmitia, M., \& Hesser, J. (1993). Why Siblings Are Important Agents of Cognitive Development: A Comparison of Siblings and Peers. Child Development, 64(2), 430-444. https://doi.org/10.1111/j.14678624.1993.tb02919.x

Brody, G. H. (1998). SIBLING RELATIONSHIP QUALITY: Its Causes and Consequences. Annual Review of Psychology, 49(1), 1-24. https://doi.org/10.1146/annurev.psych. 49.1.1

Buhrmester, D., \& Furman, W. (1990). Perceptions of Sibling Relationships during Middle Childhood and Adolescence. Child Development, 61(5), 1387-1398. https://doi.org/10.1111/j.14678624.1990.tb02869.x

Cicirelli, V. G. (1973). Effects of sibling structure and interaction on children's categorization style. Developmental Psychology, 9(1), 132-139. https://doi.org/10.1037/h0035061

Cicirelli, V. G. (1995). Sibling Relationships Across the Life Span (1 ed.). Springer US. https://doi.org/10.1007/978-14757-6509-0

Fahmi, U. N., \& Handayani, M. M. (2018). Hubungan antara dimensi sibling relationship dengan psychological well-being pada remaja yang memiliki saudara. Jurnal Psikologi Pendidikan dan Perkembangan, 7, 39-46.

Fardiyanti, A. (2017). Pengaruh sibling rivalry terhadap hubungan teman sebaya (Skripsi). UMM Institutional Repository.

Furman, W., \& Buhrmester, D. (1985). Children's Perceptions of the Qualities of Sibling Relationships. Child
Development, $\quad 56(2), \quad 448-461$. https://doi.org/10.1111/j.1467-

8624.1985.tb00119.x

J. Kelly McCoy, Gene H. Brody, \& Zolinda Stoneman. (2002). Temperament and the Quality of Best Friendships: Effect of Same-Sex Sibling Relationships. Family Relations, 51(3), 248-255.

Kamaluddin, H. (2011). Bimbingan dan Konseling Sekolah. Jurnal Pendidikan dan Kebudayaan, 17(4), 447. https://doi.org/10.24832/jpnk.v17i4.40

Kavcic, T., \& Zupancic, M. (2011). Sibling Relationship and Personality in Early/Middle Childhood From Parent'S Perception. Suvremena Psihologija, 14(2), 119-133.

Kim, J.-Y., McHale, S. M., Crouter, A. C., \& Osgood, D. W. (2007). Longitudinal linkages between sibling relationships and adjustment from middle childhood through adolescence. Developmental Psychology, 43(4), 960-973. https://doi.org/10.1037/00121649.43.4.960

Leung, A. K. D., \& Robson, W. L. M. (1991). Sibling Rivalry. Clinical Pediatrics, 30(5), 314-317. https://doi.org/10.1177/000992289103 000510

Lindell, A. K., \& Campione-Barr, N. (2017). Relative Power in Sibling Relationships Across Adolescence. New Directions for Child and Adolescent Development, 2017(156), 49-66. https://doi.org/10.1002/cad.20201

Marotta, A. K. (2015). The Relationship between Sibling Relationship Quality and Psychological Outcomes in Emerging Adulthood (Tesis) [Columbia University]. https://doi.org/https://doi.org/10.7916/ D85T3JRG

Menesini, E., Camodeca, M., \& Nocentini, A. (2010). Bullying among siblings: The role of personality and relational variables. British Journal of Developmental Psychology, 28(4), 921-939. 
https://doi.org/10.1348/026151009X4 79402

Milevsky, A. (2019). Parental Factors, Psychological Well-Being, and Sibling Dynamics: A Mediational Model in Emerging Adulthood. Marriage \& Family Review, 55(5), 476-492. https://doi.org/10.1080/01494929.201 8.1518822

Naretey, S. (2013). Perception of Stigma on the Psychological Well-Being of Siblings of Children with Intellectual Disability (Nomor 10169371). University of Ghana.

Nastasi, B., \& Borja, A. P. (2016). International Handbook of Psychological Well-Being in Children and Adolescents. In B. K. Nastasi \& A. P. Borja (Ed.), International Handbook of Psychological Well-Being in Children and Adolescents. Springer New York. https://doi.org/10.1007/978-1-49392833-0

Paula, T. S. (2012). Resilience and the role of sibling relationships among children within homeless families. In Dissertation Abstracts International: Section B: The Sciences and Engineering (Vol. 72, Nomor 8-B). University of Miami.

Pertiwi, R. G., \& NRH, F. (2019). Hubungan Antara Sibling Rivalry Dengan Psychological Well-Being Pada Siswa Kelas Vii Smp Negeri 12 Semarang. Empati, 7(4), 143-151.

Prabowo, A. (2016). KESEJAHTERAAN PSIKOLOGIS REMAJA DI SEKOLAH. JIPT, 4(2), 246-260. https://doi.org/10.22219/jipt.v4i2.352 7

Ramadhani, T., Djunaedi, D., \& Sismiati S., A. (2016). KESEJAHTERAAN PSIKOLOGIS (PSYCHOLOGICAL WELL-BEING) SISWA YANG ORANGTUANYA BERCERAI (Studi Deskriptif yang Dilakukan pada Siswa di SMK Negeri 26 Pembangunan Jakarta). INSIGHT: JURNAL BIMBINGAN KONSELING,
$5(1)$,

108. https://doi.org/10.21009/INSIGHT.05 1.16

Riska, H. A., Krisnatuti, D., \& Yuliati, L. N. (2018). Pengaruh Interaksi Remaja dengan Keluarga dan Teman serta Self-Esteem terhadap Perilaku Prososial Remaja Awal. Jurnal Ilmu Keluarga dan Konsumen, 11(3), 206218.

https://doi.org/10.24156/jikk.2018.11. 3.206

Roja, N. M. (2013). Hubungan Sibling Relationships Dengan Perilaku Delinkuensi Pada Remaja di SMAN 7 Banda Aceh. UNIVERSITAS SYIAH KUALA.

Ryff, C. D. (1995). Psychological WellBeing in Adult Life. Current Directions in Psychological Science, 4(4), 99-104. https://doi.org/10.1111/14678721.ep10772395

Sanders, R. (2004). Sibling Relationships. In J. Campling (Ed.), Journal of Chemical Information and Modeling. Macmillan Education UK. https://doi.org/10.1007/978-0-23020306-8

Saputro, K. Z. (2018). Memahami Ciri dan Tugas Perkembangan Masa Remaja. Aplikasia: Jurnal Aplikasi Ilmu-ilmu Agama, 17(1), 25. https://doi.org/10.14421/aplikasia.v17i 1.1362

Savitri, W. C., \& Listiyandini, R. A. (2017). Mindfulness dan Kesejahteraan Psikologis pada Remaja. Psikohumaniora: Jurnal Penelitian Psikologi, 2(1), 43. https://doi.org/10.21580/pjpp.v2i1.132 3

Sherman, A. M., Lansford, J. E., \& Volling, B. L. (2006). Sibling relationships and best friendships in young adulthood: Warmth, conflict, and well-being. In Personal Relationships. https://doi.org/10.1111/j.14756811.2006.00110.x

Stoneman, Z., \& Brody, G. H. (1993). 
Sibling Temperaments, Conflict, Warmth, and Role Asymmetry. Child Development, 64(6), 1786-1800. https://doi.org/10.1111/j.14678624.1993.tb04213.x

Stormshak, E. A., Bullock, B. M., \& Falkenstein, C. A. (2009). Harnessing the power of sibling relationships as a tool for optimizing social-emotional development. New Directions for Child and Adolescent Development, 2009(126), 61-77. https://doi.org/10.1002/cd.257

Sugiyatno. (2014). Standar kompetensi kemandirian. Jakarta: Departemen Pendidikan Nasional.

Thomas, P. A., Liu, H., \& Umberson, D. (2017). Family Relationships and Well-Being. Innovation in Aging, 1(3). https://doi.org/10.1093/geroni/igx025

Van Langeveld, A. D. C. (2010). Sibling Relationships, Stress, and Well-Being During Early Adolescence. Brigham Young University.

Yanuari, T., \& Rahmasari, D. (2011). Hubungan antara sibling rivalry dengan stres pada anak. Jurnal Psikologi Teori dan Terapan, 2(1), 46. https://doi.org/10.26740/jptt.v2n1.p46 $-57$ 